\title{
1 方向および 2 方向鋼構造立体骨組の耐震信頼性評価 SEISMIC RELIABILITY OF 3D 1-WAY AND 2-WAY STEEL MOMENT FRAME STRUCTURES EVALUATED BY PROBABILISTIC APPROACH
}

\author{
田川浩 之*，グレゴリーマックレイ**，ローラローズ*** \\ Hiroyuki TAGAWA, Gregory MACRAE and Laura LOWES
}

\begin{abstract}
Probabilistic evaluation of the seismic performance of 3D steel moment-frame structures is carried out for two types of framing system: two-way frames typical of construction in Japan and one-way frames typical of construction in the United States. For each framing system, four types of beam-column connections are considered: Pre-Northridge Welded-Flange-Bolted-Web, Post-Northridge Welded-Flange-Welded-Web, Reduced-Beam-Section, and Bolted-Flange-Plate connections. A suite of earthquake ground motions is used to compute the annual probability of exceedence (APE) for a series of drift demand levels and for member plastic-rotation capacity. Results are compared for the different framing systems and connection details. The two-way frames have a smaller APE for small drift demands for which members exhibit no or minimum yielding, but have a larger APE for large drift demands for which members exhibit large plastic rotations. However, the one-way frames, which typically comprise a few seismic frames with large-sized members that have relatively small rotation capacities, may have a larger APE for member failure.
\end{abstract}

Keywords : One-, Two-way Steel Frame Structures, Seismic Reliability, Displacement Demand, Plastic Rotation Capacity, Beam-depth Effect

1 方向、2 方向の鋼構造骨組、耐震信頼性、変形要求量、塑性回転能力量、梁せいの効果

\section{1. はじめに}

世界各国の建築構造物は、歴史的な様式、入手可能な材料、建設 技術、また、経済的な考慮などによって、様々の骨組形態をもって 設計される。しかしながら、一般的な鋼構造立体骨組を設計する上 で、日本と米国等の諸外国においては、明確に違った方法がとられ ている。日本で一般に用いられる鋼構造立体骨組は、図 1 (a)に示す ように、全ての柱、梁部材を剛接合し水平 2 方向に架構した構造形 式(以下、2 方向骨組)である。そこでは、全ての構造要素は地震時 において、地震による水平荷重、および建物重量による鉛直荷重を 同時に支える。一方、米国などの諸外国で一般に用いられる鋼構造 立体骨組は、図 1(d)に示寸ように、1 方向に架構した主に地震力を 支える骨組 (以下、耐震骨組) と、建物重量を支える骨組 (以下、建物 支持骨組) から構成される構造形式(以下、1 方向骨組)である。耐震 骨組の全ての柱、梁部材は剛接合され、建物支持骨組では、柱、梁 部材はウェブ接合されて構造設計上はピン接合として取り扱われる ことが一般的である。

現在、日本では、この 1 方向骨組の設計概念、即ち、耐震骨組と 建物支持骨組を明確に分離させる方法、を取り入れる動きがある。
耐震骨組と建物支持骨組とを明確に分離することで、建築構造的な 視点からは、地震後の補修が容易で損傷制御がより可能となる 2)等、また建物支持骨組の柱材が大きな曲げモーメントを受けずに概

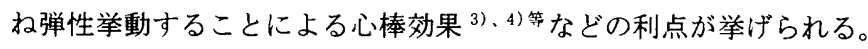
建筑計画的な視点からは、大きな柱や梁が建物内部にあまり必要で なくなるので平面計画の自由度が上がるなどの利点が挙げられる。 しかしながら、2 方向骨組では全ての部材が耐震要素であるので 個々の部材の断面寸法は一般に小さく出来るが、1 方向骨組では耐 震骨組の数が限られてくるために、ブレース材や制震部材などを用 いないとすると、個々の柱、梁部材の寸法は必然的に大きくなる。 過去に行われた柱梁部分架構の多数の載荷実験により、大きな梁せ いの接合部は一般に小さな塑性回転能力量を持つことが分かってい る5)。一方、米国では、かつてはH 形鎆を用いた 2 方向骨組であっ たが、近年、主に経済上、施工上の理由で1方向骨組に移行したの であるが 5)等、ノースリッジ地震 (1994) 後、耐震骨組で使われる大 きな部材、溶接部の寸法が梁端接合部における脆弱な亀裂の 1 つの 要因になったことが指摘され ${ }^{5)}$ 、耐震骨組の数が少なくなることに よる冗長性の欠如も懸念されてきている ${ }^{5) 、 6) 。 ~}$

\footnotetext{
* 東京工業大学都市地震工学センター COE研究員・Ph.D.

***カタタベリー大学土木工学科 準教授. Ph. D.

*** ワシントン大学土木工学科 助教授・Ph. D.

Post-Doctoral Research Fellow, CUEE, Tokyo Institute of Technology, Ph. D. Assoc. Prof., Dept. of Civil Engineering, Univ. of Canterbury, Ph. D. Assistant Prof., Dept. of Civil Engineering, Univ. of Washington, Ph. D.
} 


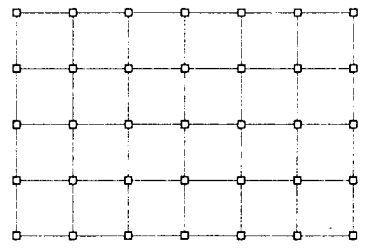

(a)2方向骨組の平面図

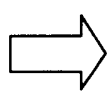

(b) 2 方向骨組の䈷略化モデルの鳥瞰図

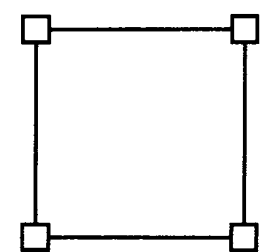

(c)2方向骨組の簡略化モデルの平面図

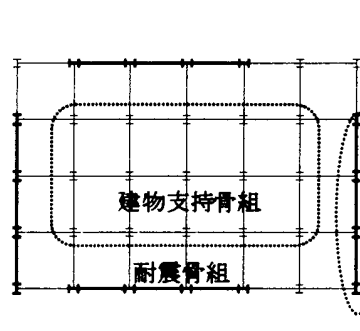

（d）1方向骨組の平面図

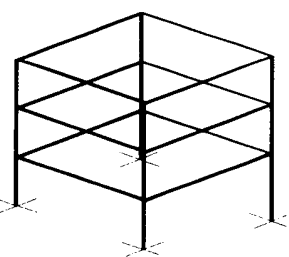

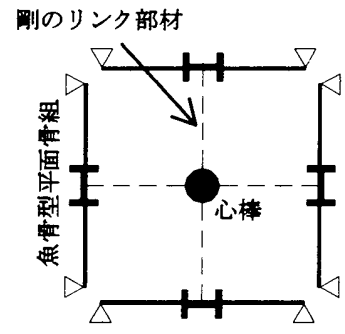

（f）1方向骨組の简路化モデルの平面図

図 11 方向、2 方向立体骨組とそれらの簡略化立体骨組モデル

日本、米国の龬構造骨組の耐震応答を比較した研究は Northridge 地震(1994)、兵庫県南部地震(1995)後、盛んに行われてきたが 7)、8)等、 梁せいの違いが耐震信頼性に及ぼす影響を数量的に考虑した比較は 筆者らの知る限り行われていない。本研究では、1 方向、2 方向の 3 階建て鋼構造立体骨組を対象に、それらの耐震性能の信頼性を(1) 様々の変形要求量レベル、(2)部材破壊レベルに対する年間超過確率 を、確率論的アプローチを用いて算出することで評価する。その際 に、1 方向、2 方向骨組の梁せいの寸法効果も考慮に入れて評価する。

\section{PEER の確率論的アプローチを用いた耐震性能評価}

1 方向、2 方向の鋼構造立体骨組の耐震性能を評価する際に、 Pacific Earthquake Engineering Research (PEER) Center の研究 者により提案され実用化されている式(1）9，10)等を用いる。この式 は、地震動強さの生起確率から建物所有者や構造設計者の意思決定 （耐震補強するか、建て替えるかなど）までの過程をすべて考慮に入 れたものであり、設計や補強時において目標とする建物の耐震性能 レベルをより明確に規定し達成させるための 1 つの手段である。ま た、その各々の評価過程で生じるばらつき量を陽の形で計算に盛り こむことが出来ることを特色とする。

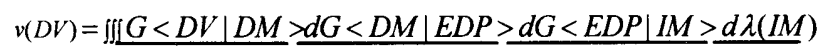

ここで、 $v(D V)$ は費用で示されるある意思決定変数 DV (Decision Valuable)の年間超過確率である。 $G\langle D V \mid D M\rangle$ は、ある与えられた損賃DM (Damage Measure)のレベルに対し て意思決定変数DVの条件付き超過確率である ${ }^{11)}$ 等。 $d G\langle D M \mid E D P\rangle$ は、ある与えられた工学要求量 EDP (Engineering Demand Parameter)に対する損傷DMの条件付き

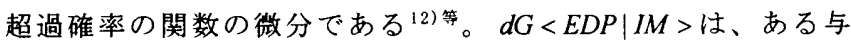
えられた地震動強さIM (Intensity Measure)に対して工学要 求量EDPの条件付き超過確率の関数の微分である ${ }^{13)}$ 等。そして、 $d \lambda(I M)$ は、地震動強さIMの年間超過確率を表す関数の微分で ある14)等。本研究では、初めの3ステップ、地震動強さIM、工
学要求量EDP、損傷DMについて統計的な評価を行い、1方向、2 方向の鋼構造立体骨組の耐震性能を評価する。

\section{1 方向、 2 方向骨組の簡略化方法}

起こりうる地震動の構造物への変形要求量の傾向を求めるために は、多数の動的解析結果が必要となる。従って、1 自由度モデルや(等 価）せん断モデルなどの簡略化モデルが一般に用いられる。本研究で は、1 方向、 2 方向骨組への変形要求量の傾向を求めるために、それ らの骨組形式の構造的特徴を捉えた簡略化立体骨組モデルを用いて 多数の動的非線形解析を行う。図 1 (a)に示す箱型断面柱で設計され た 2 方向骨組の簡略化では、図 1(b)、1(c)に示すように 4 本ずつの 柱材と梁材からなる立体骨組に置換する。ここで柱材と梁材は全て 剛に接合される。図 1 (d) に示す H 型断面の柱で設計された 1 方向骨 組の簡略化では、図 1 (e)、1(f)のように外周部の 4 つの耐震骨組を

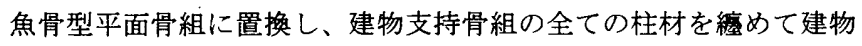
を高さ方向に貫く 1 本の柱材 (所謂、心棒)に置換する。その心棒を 4 つの魚骨型平面骨組と完全剛のリンク部材で連結する。これらの 簡略化立体骨組モデルは、元の 1 方向、2 方向の整形の鎆構造立体 骨組の地震時応答を概ね正確に追跡できる。図 2(a)、2(b) は、簡略 化立体骨組モデルと元の鎆構造立体骨組の、SAC ${ }^{15)}$ で用いられた地震 動 NF17、NF18 $8^{16)}$ を建物に斜め $45^{\circ}$ から入力した時の X、Y 方向の層 間変形の履歴を示す。1 方向、2 方向骨組ともに、簡略化立体骨組モ デルは元の鋼構造立体骨組と概ね等しい履歴応答を持つ ${ }^{3)}$ 。

図 $3(a) 、(b) に$ 本研究で用いる 1 方向、2 方向の簡略化立体骨組モ デルを示す。1 方向、2 方向骨組ともに、X、Y 方向 1 スパンの長さ は $9.14 \mathrm{~m} 、 1$ 層の高さは $3.96 \mathrm{~m}$ である。1 方向、2 方向骨組の耐震性 能比較を容易にするため、（1）1 方向の簡略化立体骨組モデルにお いて図 1 (e)の心棒で表される建物支持骨組内の柱材は考虑しない、 (2) 1 方向、 2 方向の簡略化立体骨組モデルの同一階における各々の 柱材、梁材の材料特性、及び断面 2 次モーメントは等しい(即ち、元 の 1 方向、2 方向の鎆構造立体骨組において柱材、梁材の断面 2 次 モーメントの総和が等しい)とした。設計の手順としては、まず、図 1 (a)に表される $4 \times 6$ スパンの 3 階建て 2 方向骨組を UBC (1997) ${ }^{17)}$ 
に従って設計し ${ }^{18)}$ 、それを図 3(a)の簡略化立体骨組モデルに置換し た。そしてその各層 4 本の柱、梁材を組み換えて図 3(b)に示される 1 方向骨組の簡略化立体骨組モデルを得た。その結果、1 方向、2 方 向の簡略化立体骨組モデルにおいて、柱の断面 2 次モーメント $\mathrm{I}^{\mathrm{FISH}} \mathrm{c}$ は $4.2002 \times 10^{9} \mathrm{~mm}^{4}$ 、梁の断面 2 次モーメント $\mathrm{I}_{\mathrm{b}}^{\mathrm{FISH}}$ は、X一方向の 1 、 2 階で $11.426 \times 10^{9} \mathrm{~mm}^{4} 、 3$ 階で $8.3038 \times 10^{9} \mathrm{~mm}^{4} 、 \mathrm{Y}$ 一方向の $1 、 2$ 階で 10. $664 \times 10^{9} \mathrm{~mm}^{4} 、 3$ 階で $7.7502 \times 10^{9} \mathrm{~mm}$ となった。ここで、 1 方向骨 組に対しては、図 3(b)の簡略化立体骨組モデルの1 本の梁材は、図 1 (d)の元の鋼構造立体骨組の 3 本の梁材に相当する。一方、2 方向 骨組では、図 3(a)の簡略化立体骨組モデルの1 本の梁材は、図 1 (a) の元の鎾構造立体骨組の 15 本の梁材に相当する。従って、もし、1 方向骨組と 2 方向骨組が同じ梁の断面 2 次モーメント $\mathrm{I}^{\mathrm{FISH}}{ }_{\mathrm{b}}$ を持ち、 両梁断面が相似ならば、1 方向骨組の梁材は、2 方向骨組の梁材と比 較して、 $(15 / 3)^{1 / 4} \approx 1.5$ 倍の梁せいをもつことになる。

静的、動的解析には有限要素解析プログラム DRAIN-3DX ${ }^{19)}$ を用い た。柱、梁材の寸法を求める際にはそれらの中心線を用いた。剛床 を仮定し図 3(a)、3(b)に示すように各層に完全剛の棒材を導入した。 柱材にはファイバーモデルを用い、梁材においては梁端部以外の部 分は弾性の梁要素でモデル化し、梁端部での塑性化を考虑し梁端部 に回転バネを導入した。回転バネは $3 \%$ ひずみ硬化率を持つバイリ ニアー履歴を仮定した。また、建物の 1 次固有周期と周期 0.2 秒に おいて $2 \%$ の減衰を持つようなレーリー型の減衰 ${ }^{20)}$ を用いた。

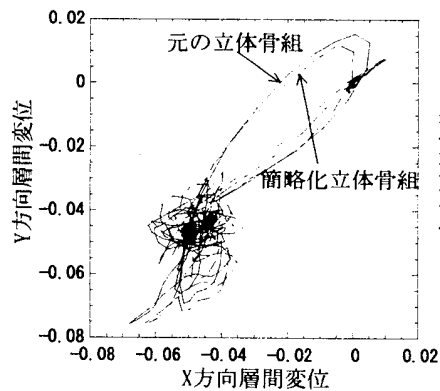

(a) 2 方向骨組

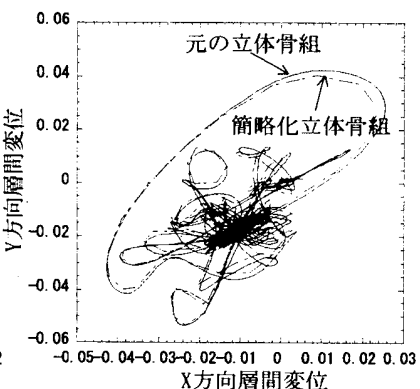

X方向層間変位

(b) 1 方向骨組
図 2 鋼構造立体骨組と簡略化立体骨組モデルの変位応答の比較

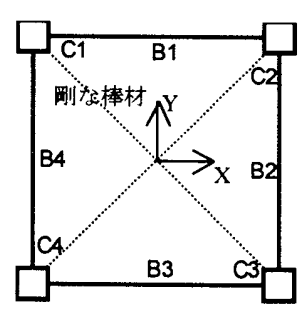

(a) 2方向骨組の箱略化モデル

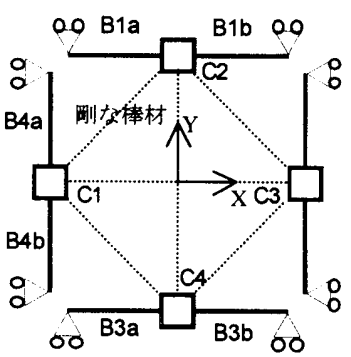

(b) 1方向骨組の䈥略化モデル
図 3 解析対象の 1 方向、2 方向の簢略化立体骨組モデル

\section{1 方向、2 方向骨組の權造特性}

1 方向、2 方向骨組の一般的な構造特性を捉えるために、図 3(a)、 3 (b)に示す 3 階建ての简略化立体骨組モデルに対して 1 方向水平力 載荷の静的漸增解析を行った。図 4(a)、4(b)に 1 階の層間部分骨組 の層せん断力(を建物重量で除した値)一層間変形角関保、建物全体 の 1 階部分の層せん断力(を建物重量で除した值)-最上階変形角(最 上階での変形量を建物高さで除した値)関係の骨格曲線を示す。層間 部分骨組、建物全体に対しても、2 方向骨組は 1 方向骨組よりもや
や大きな剛性を持つ。これは 2 方向骨組では全ての柱梁は剛に接合 され、4 本の柱材、 2 本の梁材が 1 方向載荷に対して剛な骨組を形成 し(図 3(a) でX 方向の載荷に対し、柱 $\mathrm{C} 1 、 \mathrm{C} 2$ と梁 $\mathrm{B} 1 、$ 柱 $\mathrm{C} 3 、 \mathrm{C} 4$ と 梁 B3)、1 万向骨組では、 2 本の柱材と 4 本の半スパン分の梁材 (2 本の 1 スパンの梁材に相当)が、1 方向載荷に対して剛な骨組を形成 する(図 3(b)でX 方向の載荷に対し、柱 $\mathrm{C} 2$ と梁 $\mathrm{B} 1 \mathrm{a} 、 \mathrm{~B} 1 \mathrm{~b} 、$ 柱 $\mathrm{C} 4$ と 梁 B3a、B3b) からである。1 方向、2 方向骨組の層間部分骨組は 1 方 向載荷に対して、梁端部に同じ数である 4 つの塑性ヒンジをもつ(X 方向載荷に対し、2 方向骨組では図 3(a)の梁 B1、B3 の両端部、1 方 向骨組では図 3(b) の梁 B1a、B3a の右端部、梁 B1b、B3b の左端部) ので図 4(a)に示すように同じ降伏強度をもつ。しかし骨組全体では、 1 階柱脚部に形成される塑性ヒンジの数は 2 方向骨組の方が 1 方向 骨組よりも多いために (2 方向骨組では図 3(a)の柱 C1、C2、C3、C4 の柱脚部、1 方向骨組では図 3(b) の柱 C2、C4 の柱脚部)、図 4(b)に 示すように 2 方向骨組の方が大きな初期岡性、降伏強度を持つ。

初期岡性、降伏強度の点では 2 方向骨組の方が 1 方向骨組よりも 有利になるが、変形集中の点では不利になる。図 5 は 1 階部分の層 間変形角を最上階変形角で除した值で定義される 1 階部分の変形集 中率を示す。両骨組は弾性域にある時は 1 階部分の変形集中率は 1.0 より小さい。しかし、塑性化が始まると 2 方向骨組は大きな 1 階部 分の変形集中率を持ち、最上階変形角が $5 \%$ の時で約 1.6 に達する。 これは、全ての 4 本の柱材は同様の曲げモーメント分布を呈し、塑 性ヒンジが 1 層部分の柱の上下端で同時に形成されることにより変 形集中が起こるからである。1 方向骨組は小さな 1 階部分の変形集 中率を呈し大きな最上階変形角においても約 1.2 までにしか増加し ない。これは、1 方向骨組では、構面外の柱材(図 3(b)の C1 とC3) が梁材からの曲げモーメント入力がないので弾性举動して、建物の 高さ方向により均一な変形分布を与えるからである。水平 1 方向で 考えると、2 方向骨組では 1 本の梁材は 1 本の柱材に架構し柱梁の 耐力比は 1.38 となる。一方、1 方向骨組では 2 本の梁材が 1 本の柱 材に架構するので柱梁の耐力比はその半分の 0.69 である。即ち、1 方向骨組では柱梁の耐力比が 2 方向骨組よりも小さいにも関わらず、 弾性に留まる構面外の柱材の存在により小さな変形集中を呈する。

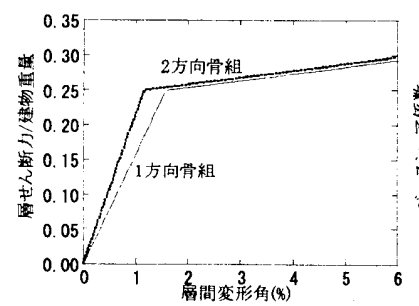

（a）層間部分骨組

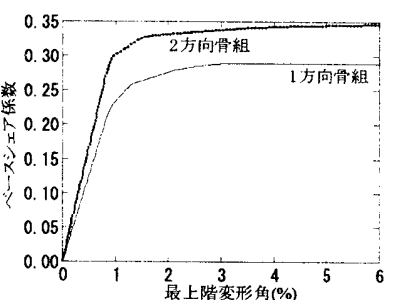

（b）建物全体
図 41 方向、 2 方向の水平荷重-水平変形関倸

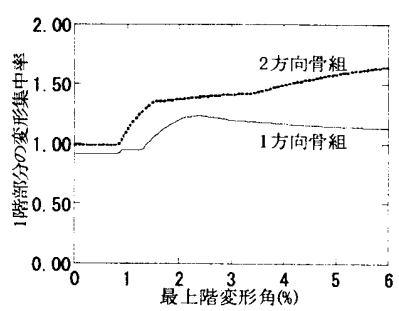

図 51 方向、2 方向立体骨組の 1 階部分における変形集中率 


\section{5. 地震動強さの年間超過確事}

建物の耐震性能を評価するためには第一段階として、建物に入力 される地震動強さの碓率、式(1)の PEER の式では入(IM)を予測する 必要がある。本研究では、PEER の方法にならい、地震動強さの指 標 IM として建物の固有周期を持つ 1 質点弹性モデルの最大加速度 応答 $\mathrm{S}_{\mathrm{a}}$ を用いる。そのために、SAC プロジェクト ${ }^{15)}$ で用いられた 米国カリフォルニア州における硬めの地盤における 50 年 $50 \%$ (年間 超過確率 0.01376)の 20 個の地震動 ${ }^{16}$ )、50 年 $10 \%$ (年間超過確率 0.00210 )の 20 個の地震動 ${ }^{16)} 、 50$ 年 $2 \%$ (年間超過確率 0.00040 )の 20 個の地震動 ${ }^{16}$ に対して、弹性 1 自由度系のモデル(固有周期は、2 方 向、 1 方向骨組の固有周期である 0.81 秒と 0.89 秒)を動的解析し、 地震動強さの年閒超猧関数である $\lambda(I M)=\lambda\left(S_{a}\right)$ を算出した。固有周期 が 0.81 秒の時、50 年 $50 \% 、 50$ 年 $10 \% 、 50$ 年 $2 \%$ の各々 20 個の地震 動に対する最大加速度応答の対数平均值は $0.55 \mathrm{~g} 、 1.05 \mathrm{~g} 、 1.99 \mathrm{~g}$ であ る。固有周期が 0.89 秒の時は、 $0.56 \mathrm{~g} 、 0.98 \mathrm{~g} 、 1.87 \mathrm{~g}$ である。これら のデー夕を用いて連続関数である入 $\left(S_{a}\right)$ を算出するために図 6 のよう に回帰解析を行った。ここで、 $\lambda\left(S_{a}\right)$ の関数の形式として Cornell 等 14) によって提案されている $\lambda\left(\mathrm{S}_{\mathrm{a}}\right)=\mathrm{k}_{0} \mathrm{~S}_{\mathrm{a}}{ }^{-k}$ を本研究でも用いる。この関 数形式を用いると X、Y 軸を対数目盛りの形式に設定すると回㷌曲 線は 1 本の直線となり最小自乗法により係数 $\mathrm{k}_{\mathrm{o}} 、 \mathrm{k}$ が求められる。 その結果として、 1 方向、 2 方向の 3 階建て銅構造立体骨組の固有周 期における最大加速度応答の年間超過関数として式(2)および式(3) が得られる。ある最大加速度応答に対する年間超過確率は固有周期 が 0.89 秒の時と比較して 0.81 秒の方が僅かに大きいことが分かる。

$$
\lambda(I M)=\lambda\left(S_{a}\right)=0.00258 S_{a}^{-2.774}
$$

$$
\lambda(I M)=\lambda\left(S_{a}\right)=0.00233 S_{a}^{-2.917}
$$

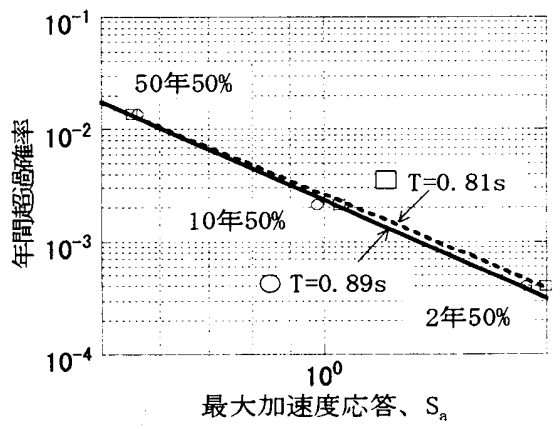

図 6 加速度スペクトルのハザード関数

\section{6. 建物に要求される变形量の確率的評価}

\section{1 様々の地震動强さに対する变形要求量}

本研究では式(1)の $\mathrm{EDP}$ (工学要求量)の尺度として最大層間変形角 (SDA)を用いる。 $\mathrm{SAC}^{15)}$ で用いられた 40 個の直下型 $(\mathrm{NF})$ の地震動 ${ }^{16)}$ を潮增した地震動群に対して濑增型非線形動的解析 ${ }^{211}$ を行い、1 方 向、2 方向の简略化立体骨組モデルの最大層間变形量を算出した。 1 方向、2 方向入力を行ったが、2 方向入力の結果を図 7 (a)、7(b)に 示す。これらのデータを基にある地震動強さ $\mathrm{S}_{\mathrm{a}}$ の值に対するSDA の 超過確率 $\mathrm{G}<\mathrm{SDA} \mid \mathrm{S}_{\mathrm{a}}>$ が算出できる。例えば、1 方向入力下の 1 方向骨 組に対して $\mathrm{S}_{\mathrm{a}}=1.5 \mathrm{~g}$ に倍率を挂けた 40 個のうち 12 個の地震動に 対して SDA が 5\%を超えるので $\mathrm{G}\left\langle\mathrm{SDA}=5 \% \mid \mathrm{S}_{\mathrm{a}}=1.5 \mathrm{~g}\right\rangle=0.3$ となる。

\section{2 様々の変形要求量レベルに対する年間超過確率}

ある地震動強さの生起確率とその加速度応答に対する最大層間変 形要求量の超過確率を掛けて積分することで、ある工学要求量 EDP に対する年間超過確率 $v(\mathrm{EDP})$ が算出することが出来る。これは式 (4)〜 (6)で表現される。

$$
\begin{aligned}
v(E D P) & =\int G<E D P \mid I M>d \lambda(I M) \\
& =\int G<S D A \mid S_{a}>d \lambda\left(S_{a}\right) \\
& \approx \sum G<S D A \mid S_{a}>\cdot \lambda\left(S_{a}\right) \cdot \Delta S_{a}
\end{aligned}
$$

3 階建ての 1 方向、 2 方向骨組の 1 方向入力時における最大層間変 形角の年間超過関数 $v(\mathrm{EDP})$ を図 $8(\mathrm{a})$ で比較する。最大層間変形角が $2 \%$ 以下の時は、3 階建て 2 方向骨組の方が小さな $v(\mathrm{EDP})$ を持つ。こ れは、図 4(b)のように 2 方向骨組は 1 方向骨組よりも大きな初期剛 性、大きな降伏強度を持ち、最大層間変形角が $2 \%$ 以下の時は、降伏 に至るまでの構造特性が建物挙動に大きな影響を及ぼすからと考え られる。しかし、最大層間変形角が $4 \%$ 以上になると、2 方向骨組は

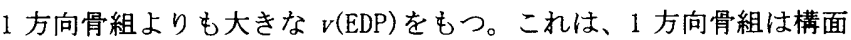
外の柱材 (図 3(b) の柱 C1 と C3) があるためにそれらが地震時におい て概ね弾性挙動をするため、ある層における塑性メカニズムが抑制 され、特定層の変形集中が緩和されるためである。これは、図 5 に 示寸静的漸增解析による 1 層部分の変形集中率の結果とも一致する。

2 方向入力での様々の $v(E D P)$ を、1 方向、2 方向骨組に対して図 8 (b)で比較する。ここでも 2 方向骨組は 1 方向骨組と比較して、小

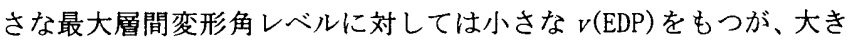
な最大層間変形角レベルに対しては大きな $v(\mathrm{EDP})$ をもつことが分 かる。これは、2 方向骨組では大きな地震動に対して 4 本の柱材が 概ね同じ挙動をするために概ね同時刻に塑性化が進行し、それによ り特定層の変形集中が起こりやすくなるからである。

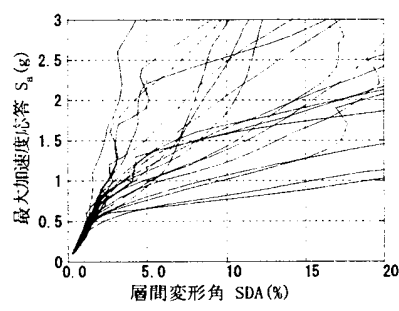

(a) 2 方向骨組

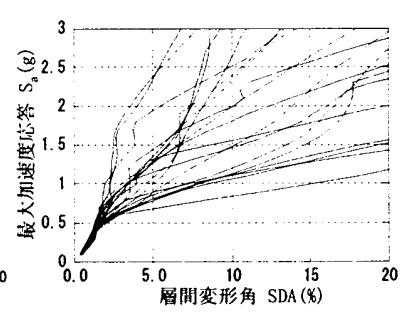

（b）1 方向骨組
図 7 様々の地震動レベルに対する層間変形量 $(2$ 方向入力 $)$

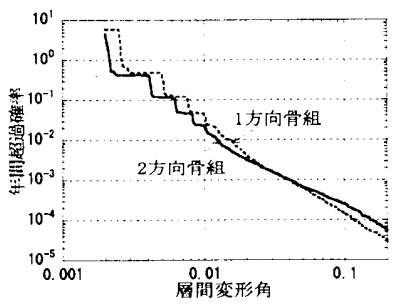

(a) 1 方向入力

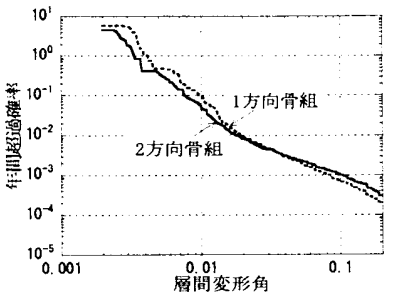

(b) 2 方向入力
図 8 様々の変形要求量に対する年間超過確率 


\section{7. 柱梁接合部の塑性回転能力畕の統計值}

構造物の変形能力量は一般に部分骨組や部材に対する多数の載荷 実験より求められる。FEMA-355D 組に対する多数の載荷実験より求められた柱梁接合部の塑性回転能 力量の統計值 (標準値と標準偏差) を提供している。図 9 に示す Pre-Northridge、Post-Northridge、Reduced-Beam-Section(RBS)、 Bol ted-Flange-Plate (BFP) 接合部に対する塑性回転能力量の統計值 を表 1 に示す。ここで $\mathrm{d}_{\mathrm{b}}(\mathrm{mm})$ は梁せいである。柱梁接合部の塑性回 転能力量として FEMA-355D 5 は 2 つのレベルを挙げており、それらは 1) 初めの破断が柱梁接合部に起こるか、接合部耐力が全塑性モーメ ントの $80 \%$ 以下に低下する時の最大塑性回転能力量 (本研究ではこ れを「部材破壊」と呼ぶ)、(2) 柱梁接合部が建物重量をもはや支え る能力を失う時の最大塑性回転能力量である。本研究では 1 つ目の 部材破壊レベルに対して耐震評価を行い、6 章の変形要求量の算出 においては部材破壊レベルまで梁端部に形成される塑性ヒンジはひ ずみ硬化率 $3 \%$ のバイリニアーの履歴性状で挙動すると仮定した。信 頼性解析を行うには、工学要求量 (EDP) と損傷 (DM) は同じ尺度で表現 される必要がある。FEMA/SAC のプログラム ${ }^{15)}$ では層間変形量 (SDA) を建物全体の安定性や柱梁接合部の局所的な挙動を指し示寸基本的 な指標として用いており、塑性回転能力量と層間変形能力量の相関 式として式(7)を用いている ${ }^{22)}$ 。

$$
S D A_{i}=\theta_{i}+0.01
$$

ここで、SDA $\mathrm{S}_{\mathrm{i}}$ は $\mathrm{i}$ 階における層間変形能力量、 $\theta_{i}$ は $\mathrm{i}$ 階における柱 梁接合部の塑性回転能力量である。最大層間変形角の正規分布の確 率密度関数は式 (8)で与えられる。

$$
\begin{aligned}
& f(S D A)=\frac{1}{\sigma_{P} \sqrt{2 \pi}} \exp \left[-\frac{1}{2}\left(\frac{S D A-S D A_{\text {mean }}}{\sigma_{P}}\right)\right] \\
& S D A_{\text {mean }}=\theta_{\text {mean }}+0.01
\end{aligned}
$$

ここで、 $\theta_{\text {mean }}$ は柱梁接合部の塑性回転能力量の標隻値、 $\sigma_{p}$ は標淮偏 差である。式(9)の右辺の 0.01 は式(7)による。表 1 のように、RBS、 BFP の塑性回転能力量は梁せい $\left(\mathrm{d}_{\mathrm{b}}: \mathrm{mm}\right)$ の関数となっており、梁せい が大きくなるほど標準值も小さくなる。梁せい $\mathrm{d}_{\mathrm{b}}$ が大きくなると塑 性回転能力が小さくなるのは、梁せいの大小に関わらず梁縁部での 最大ひずみの量は概ね同じであるが、それを梁せいの半分で割った 值である最大曲率は大きな梁せいの方が小さくなる。曲率を塑性ヒ ンジの長さで積分した值が塑性回転角となるので、大きな梁せいの 方が塑性回転能力量は小さくなる。Pre-Northridge、 Post-Northridge 接合部に関しては、梁せいをパラメーターにした 実験結果のサンプル数が少ないので、表 1 に示寸塑性回転能力量の 標準值は梁せい $d_{b}$ の関数になっていないが、これらの接合部に対し ても梁せいが大きくなるに従って塑性回転能力量は小さくなると考 えられる ${ }^{5)}$ 。梁せいが $254 \mathrm{~mm}$ (10inch)、508 mm (20inch)、762 mm (30inch)の場合の RBS 接合部、BFP 接合部を持つ骨組の表 1 に示さ れる層間変形能力量の累積確率を図 $10(\mathrm{a}) 、 10(\mathrm{~b})$ に示す。
表 1 塑性回転能力量の標準値と標準偏差

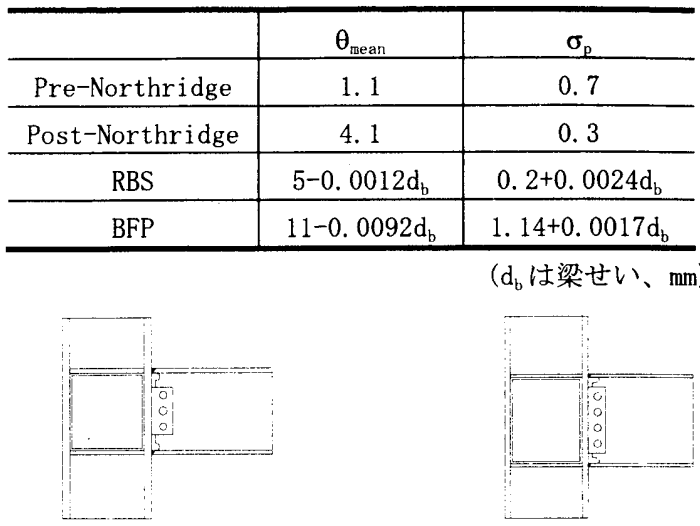

(a) Pre-Northridge接合部

(b) Post-Northridge接合部

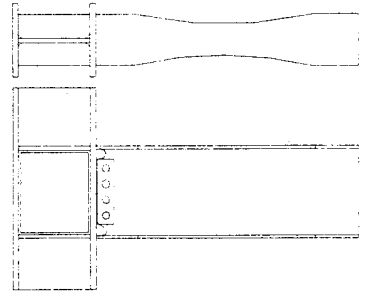

(c) RBS接合部

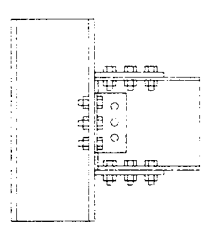

(d) BFP接合部
図 94 種類の接合部の詳細図

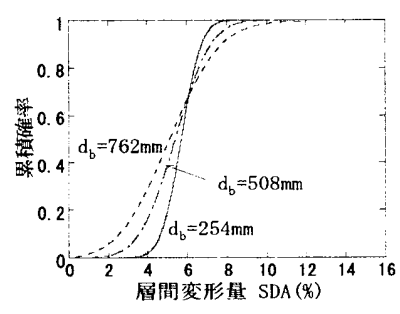

(a) RBS 接合部

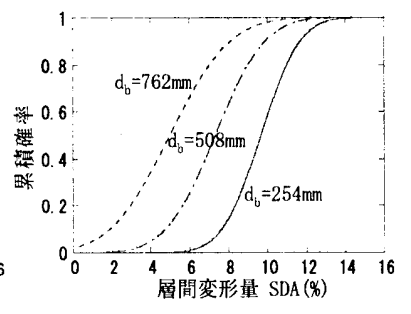

(b) BFP 接合部
図 10 RBS、BFP 接合部を持つ部分骨組の層間変形能力量

\section{8. 变形要求量と変形能力量を用いた信頼性解析}

本章では 1 方向、2 方向骨組の部材破壊の年間超過関数を 6 章で 算出した変形要求量の統計値と 7 章の変形能力量の統計值を用いて 算出する。本研究では、「最大層間変形量で表される変形要求量 S」 が、7章に述べた「初めの破断が柱梁接合部に起こる時か、耐力が 全塑性モーメントの $80 \%$ 以下に降下する時の最大層間変形量で表さ れる変形能力量 R」を超える状態を「部材破壊」と呼ぶ。破壊確率 は式(10)で算出できる ${ }^{23) 。 ~}$

$$
p_{f}=P(R<S)=\int_{0}^{\infty}\left[1-F_{s}(r)\right] f_{R}(r) d r
$$

ここで、 $\mathrm{f}_{\mathrm{R}}(\mathrm{r})$ は変形能力量の確率密度関数 $(\mathrm{PDF})$ であり、 $\mathrm{F}_{\mathrm{S}}(\mathrm{r})$ は変 形要求量の累積分布関数 $(\mathrm{CDF})$ である。地震動強さレベルの範囲 $\left[S_{a}-\frac{\Delta}{2}<X_{i}<S_{a}+\frac{\Delta}{2}\right]$ に対する破壊確率は式(11)、(12)で表される。

$$
\begin{aligned}
p_{f}\left(S_{a}\right) & =P\left(R<S\left(S_{a}\right) \mid S_{a}-\frac{\Delta}{2}<X_{i}<S_{a}+\frac{\Delta}{2}\right) \\
& =\int_{0}^{\infty}\left[1-\left.F_{s}(r)\right|_{S_{a}}\right] f_{R}(r) d r
\end{aligned}
$$


ここでR，は層間変形能力量、 $\Delta$ は最大加速度応答 $\mathrm{S}_{\mathrm{a}}$ で表される地震 動強さの増分、 $X_{1}$ はある最大加速度応答レベルの値である。

\section{1 变形要求量と变形能力鲾の統計値の重ね合わせ}

破壊確率を求めるために式(10)を用いるには、1）補完累積分布関 数 $1-F_{S}(r)$ と 2) 変形能力量の確率分布関数 $f_{P}(r)$ を求める必要が ある。図 $11(\mathrm{a}) 、(\mathrm{~b})$ は、2 方向骨組において $\mathrm{S}$ 絮 $1.5 \mathrm{~g}$ および $3.0 \mathrm{~g}$ の地震動の 1 方向入力、2 方向入力に対する変形要求量の補完累積 分布関数 $1-F_{S}(r)$ 、図 $11(\mathrm{c}) 、(\mathrm{~d})$ は、1 方向骨組において $S_{a}$ が $1.5 \mathrm{~g}$ および $3.0 \mathrm{~g}$ の地震動の 1 方向入力、 2 方向入力に対する変形要求量

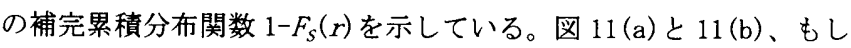
くは図 11 (c)、(d)を比較すると、明らかに 2 方向入力の場合のほう が 1 方向入力の場合よりも層間変形角の要求量が大きいことが分か る。また、図 $11(\mathrm{a})$ から (d) に、変形要求量の曲線に図 9 に示す 4 種 類の柱梁接合部を持つ骨組の層間変形能力量 $f_{R}(r)$ の確率密度関数 を重ね合わしている。RBS 接合部と BFP 接合部の梁せいは 2 方向骨 組に対しては $508 \mathrm{~mm}$ (20inch)を1方向骨組に対しては $762 \mathrm{~mm}$ (30inch) を想定している。

\section{2 地震動強さ $\mathrm{S}_{\mathrm{a}}$ に対する部材破棲確率}

変形要求量の補完累積分布関数 $1-F_{S}(r)$ と変形能力量の確率密度 関数 $f_{R}(r)$ を措け合わせて式(12)の数值積分を行い、各々の地震動 強さレベル $S_{a}$ に対する部材破壊の確率を求めた。図 $12(\mathrm{a})$ と 12 (b) は 4 種類の接合部を持つ 2 方向骨組において、 1 方向入力、 2 方向入 力に対して、ある地震動強さレベル $S_{a}$ における部材破壊の確率を 示す。図 12 (c) と 12 (d) は 4 種類の接合部を持つ 1 方向骨組において、 1 方向入力、 2 方向入力に対して、ある地震動強さレベル $S_{a}$ におけ る部材破壊の確率を示す。梁せいは、2 方向骨組では $508 \mathrm{~mm}$ ( $20 \mathrm{inch}) 、$ 1 方向骨組では 762mm（30inch）と想定している。図より全ての場合 で、Pre-Northridge の接合部を持つ骨組は、他の接合部を持つ骨組 よりもある地震動強さ $S_{a}$ レベルに対して大きな部材破壊確率を持 つことが分かる。また、 2 方向骨組では 1 方向、2 方向入力ともに、 BFP 接合部が Post-Northridge、RBS 接合部よりもやや小さな部材破 懐の確率を示す。これは、図 12 (a)、12(b)に示すように、BFP 接合 部は梁せいが $508 \mathrm{~mm}$ (20inch)の時は Post-Northridge、RBS 接合部 よりも全体に大きな塑性変形能力量を持つからである。しかし、1 方向骨組では 1 方向、 2 方向入力ともに、BFP 接合部は RBS 接合部と 概ね同じ部材破壊の確率を示す。

\section{3 部材破棲の年間超過確率}

部材破壊の年間超過確率は、式(13)のように $P\left[S_{a}-\frac{\Delta}{2}<X_{i}<S_{a}+\frac{\Delta}{2}\right]$ で表される地震動の年間超過確率の増分量 を、ある地震動強さレベル $S_{a}$ に対する破壊確率に掛け合わして足し 合わせることで求められる。ここで地震動強さの増分 $\Delta$ を $0.1 \mathrm{~g}$ と設 定した。また、式(15)の $H\left(S_{a}\right)$ は 2 方向、1 方向骨組の固有周期に対 して式(2)、(3)で表される。

$$
\begin{aligned}
& A P E(\text { fail })=\sum\left\{P\left[S_{a}-\frac{\Delta}{2}<X_{i}<S_{a}+\frac{\Delta}{2}\right] \cdot p_{f}\left(S_{a}\right)\right\} \\
& \cong \sum\left\{P\left[S_{a}-\frac{\Delta}{2}<X_{i}<S_{a}+\frac{\Delta}{2}\right] \cdot \int_{0}^{\infty}\left[1-\left.F_{s}(r)\right|_{S_{a}}\right] f_{R}(r) d r\right\}
\end{aligned}
$$

$$
\left.\cong \sum\left\{\frac{d H\left(S_{a}\right)}{d S_{a}} \cdot \Delta\right] \cdot \int_{0}^{\infty}\left[1-\left.F_{s}(r)\right|_{S_{a}}\right] f_{R}(r) d r\right\}
$$

表 2 は、算出した 1 方向、2 万向骨組における部材破壊に対する 年間超過確率を示す。表 2 は、 $S_{a}=0.1 \mathrm{~g}$ に対する確率を含めた場合 で、括弧の中の数字は、 $S_{a}=0.1 \mathrm{~g}$ の場合を除いた場合の部材破壊に 対する年間超過確率を示す。これは、 $P\left[S_{a}-\frac{\Delta}{2}<X_{i}<S_{a}+\frac{\Delta}{2}\right]$ が、 $S_{a}=0.1 \mathrm{~g}$ に対して非常に大きくなり、これが年間超過確率に多大な 影響を及ぼすからである。4つの接合部の種類の全てに対して考慮 し、梁せいは 2 方向骨組で $508 \mathrm{~mm}$ (20inch)を、1 方向骨組に対して は 762mm (30inch) を想定した。表 2 より次のことが分かる。

1. 2 方向、1 方向骨組に対しても、2 方向入力の場合は、1 方向 入力と比較して、部材破壊に対する年間超過確率は著しく大 きくなる。

2. もし、Pre-Northridge、RBS、BFP の接合部が用いられるなら、 2 方向骨組は 1 方向骨組よりも、小さな部材破壊の年間超過確 率を持つ。しかし、Post-Northridge 接合部が使われると、2 方 向骨組は僅かに大きな部材破壊の年間超過確率を持つ。

3. 部材破壊の年間超過確率は、Pre-Northridge 接合部が用いられ ると 1 方向骨組に対しても、2 方向骨組に対しても、非常に大 きくなる。つまり、Post-Northridge、RBS、BFP 接合部は、特 に小さな梁せいをもつ 2 方向骨組に対して、部材破壊の年間 超過確率を低減するために非常に効果的である。

\section{4 様々の梁せいに対する部材破壊の年間超過確率}

図 13(a) と13(b)は、1 方向、2 方向入力下における RBS と BFP 接 合部を持つ 3 階建て 2 方向骨組の様々の梁せいに対する部材破壊の 年間超過確率を示す。BFP 接合部は、梁せいが $610 \mathrm{~mm}$ (24inch)を超 えると、僅かに大きな部材破壊の年間超過確率を示す。図 13(c)、13(d) に、 1 方向、 2 方向入力下における RBS と BFP 接合部を持つ 3 階建 て1方向骨組の様々の梁せいに対する部材破壊の年間超過確率を示 す。ここでも、BFP 接合部は RBS 接合部よりも梁せいが $610 \mathrm{~mm}$ (24inch)を超えると僅かに大きな部材破壊の年間超過確率を示す。

図 14(a)と 14(b)は、1 方向、2 方向入力下における、RBS 接合部を もつ 3 階建て 1 方向、2 方向骨組における様々の梁せいに対する部 材破壊の年間超過確率を示している。図 14(c)と 14(d)は、それらの BFP 接合部を持つ骨組における年間超過確率を示している。1 方向、 2 方向骨組に対しても、梁せいが概ね $508 \mathrm{~mm}$ (20 $\mathrm{jnch})$ を超えると、 部材破壊の年間超過確率が著しく増加することが分かる。もし、2 方向骨組の梁せいが 508mm (20inch)で 1 方向骨組の梁せいが $762 \mathrm{~mm}$ (30inch)であるとすると、1 方向骨組の方が 2 方向骨組よりも著しく 大きな部材破壊の年間超過確率を持つことが分かる。

本研究では 1 方向、2 方向骨組の耐震性能を評価する上で、梁せ いの違いによる部材の塑性回転能力量に注目しそれを唯一の構造物 側の不確定性として取り扱った。鎆構造部材には塑性変形能力のみ ならず、降伏応力度、残留忘力度、初期不整等の不確定要因も存在 し、これらの影響によって部材の耐力 (全塑性モーメント)も不確定 量となる。また、複数の部材で構成される骨組では、各部材間の耐 力や変形能力の統計的な相関性が骨組全体の統計的性質に大きく影 響する。これらの不確定性については今後の研究課題としたい。 


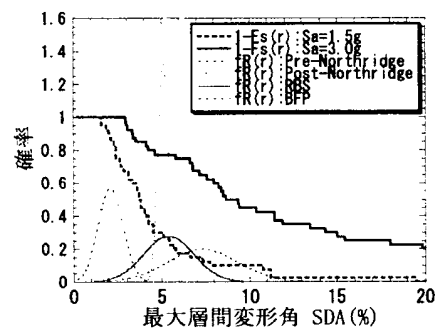

(a) 2 方向骨組、1 方向入力

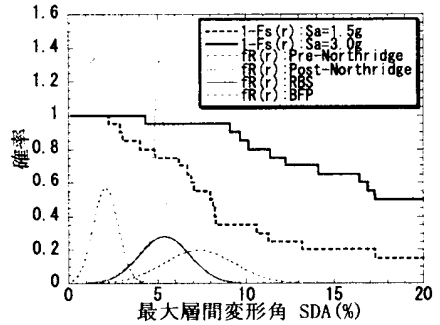

(b) 2 方向骨組、2 方向入力

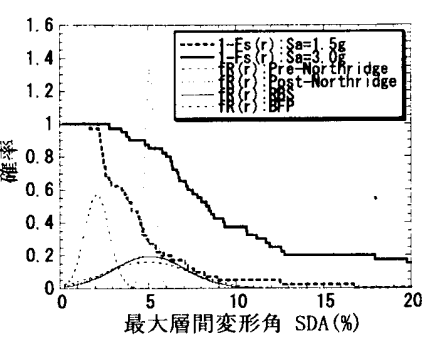

(c) 1 方向骨組、1 方向入力

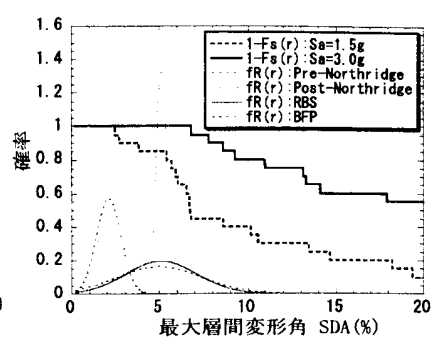

(d) 1 方向骨組、 2 方向入力

図 11 Post-Northridge 接合部を持つ 1 方向、2 方向骨組に対する 1 方向、2 方向入力時の変形要求量と変形能力量

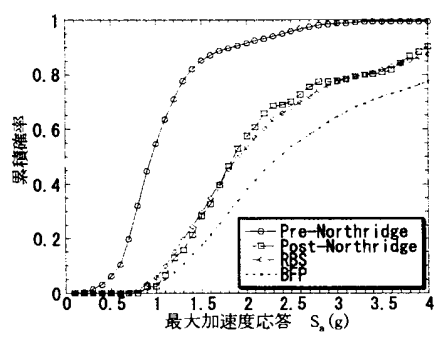

(a) 2 方向骨組、1 方向入力

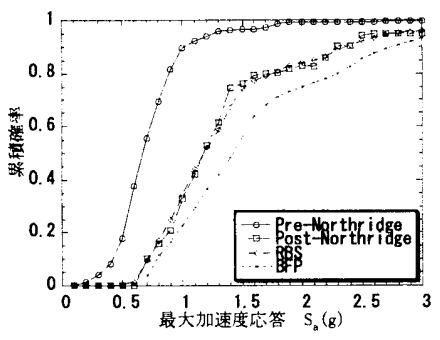

(b) 2 方向骨組、2 方向入力

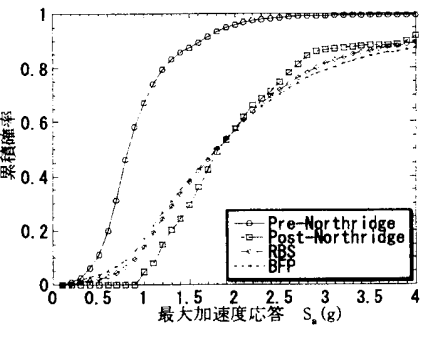

(c) 1 方向骨組、1 方向入力

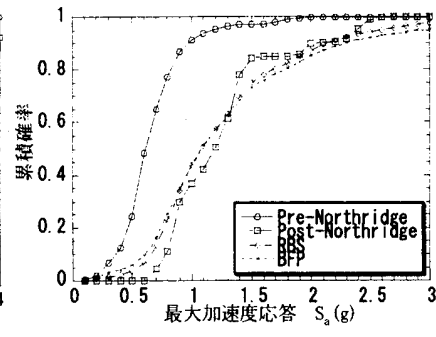

(d) 1 方向骨組、 2 方向入力

図 12 ある地震動強さレベルに対する部材破壊確率

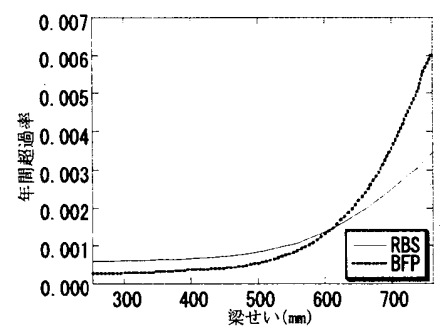

(a) 2 方向骨組、1 方向入力

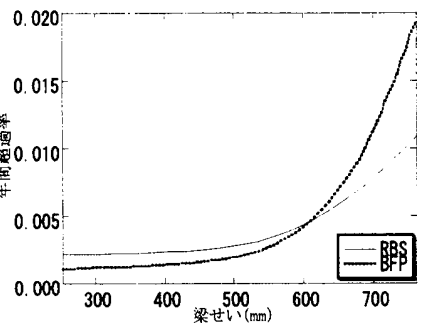

(b) 2 方向骨組、2 方向入力

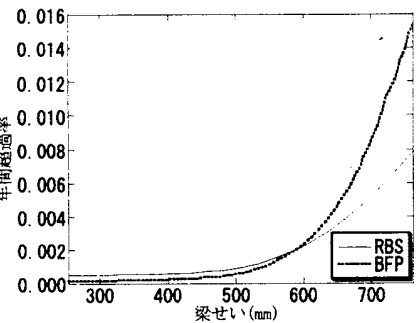

(c) 1 方向骨組、1 方向入力

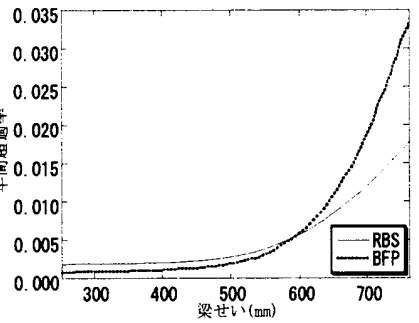

（d） 1 方向骨組、2 方向入力

図 13 様々の梁せいの接合部を持つ 1 方向、2 方向骨組における部材破壊の年間超過確率

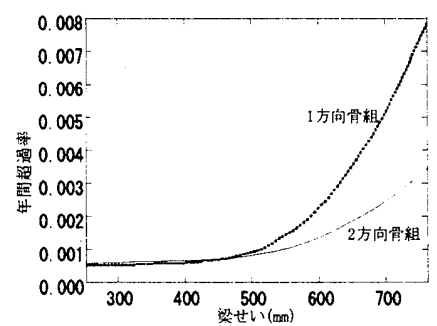

(a) 1 方向入力、RBS 接合部

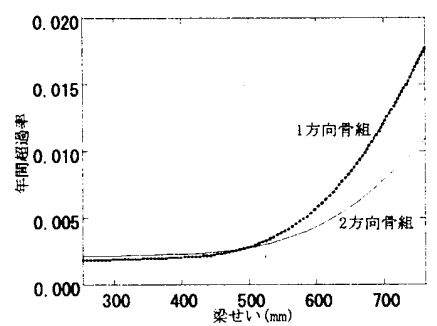

(b) 2 方向入力、RBS 接合部

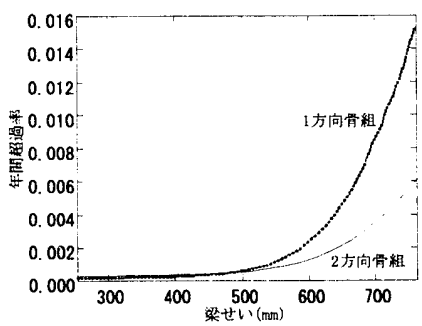

(c) 1 方向入力、BFP 接合部

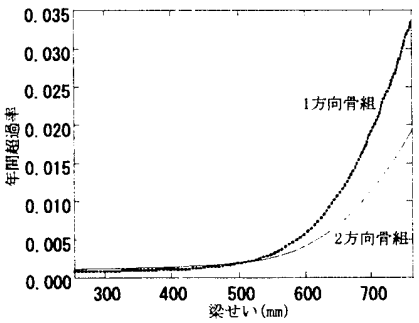

(d) 2 方向入力、BFP 接合部

図 14 様々の梁せいの RBS、BFP 接合部を持つ 1 方向、2 方向骨組における部材破壊の年間超過確率

表 2 部材破壊に対する年間超過確率 $\left(\times 10^{-4}\right)$

\begin{tabular}{c|c|c|c|c}
\hline \multirow{2}{*}{} & \multicolumn{2}{|c|}{ 2方向骨組 } & \multicolumn{2}{c}{ 1方向骨組 } \\
\cline { 2 - 5 } & 1方向入力 & 2方向入力 & 1方向入力 & 2方向入力 \\
\hline Pre-Northridge & $89(80)$ & $253(181)$ & $184(129)$ & $430(264)$ \\
\hline Post-Northridge & $7(7)$ & $24(24)$ & $6(6)$ & $21(21)$ \\
\hline RBS & $9(8)$ & $28(27)$ & $79(40)$ & $178(77)$ \\
\hline BFP & $6(5)$ & $20(19)$ & $153(70)$ & $336(122)$ \\
\hline
\end{tabular}




\section{9. 結論}

3 階建ての 1 方向、2 方向鋼構造立体骨組を対象に、多数の非線 形動的解析より得られた変形要求量の統計值と、多数の部材载荷実 験より得られた変形能力量の統計值をもとにして、耐震信頼性の評 価を行った。本研究で得られた主な要点、知見を以下に䌖める。

1. 1 方向、2 方向の立体整形骨組は、魚骨型平面モデルを組み合 わせた簡略化立体骨組モデルに置換でき、変形要求量の予測 のための非線形動的解析を効率よく行うことが出来る。

2. 2 方向立体骨組は 1 方向立体骨組と比較して、大きな弾性剛性、 降伏強度を持ち、約 $2 \%$ までの変形要求量レベルに対しては小 さな年間超過確率を示すが、 $4 \%$ を超える大変形要求量レベル に対しては大きな年間超過確率を示した。これは 2 方向立体 骨組ではその均一性によりある特定層の全ての柱材が概ね同 一時刻に塑性化を起こし変形集中をもたらすからである。

3. 梁せいが $508 \mathrm{~mm}$ (20 inch)を超えると、柱梁接合部の塑性回転 能力量が小さくなるため、建物の部材破壊に対する年間超過 確率が著しく増加する。従って、小さな梁せいをもつ 2 方向 骨組は、大きな梁せいを持つ 1 方向骨組と比較して、一般に 小さな部材破壊に対する年間超過確率を持つ。

耐震設計にもグローバリズム化が進行する現在、筆者らは日本の 2 方向鎆構造骨組は伝統的な木造軸組構造において柱梁部材を立体 格子状に組み合わせる感覚から生まれた日本特有の骨組形式である と考え、本研究では耐震構造の視点からその小さな梁せいが建物の 部材破壊の確率を低減できるという長所を明確に示すことを研究動 機とした。本研究で用いた実験データ、地震動の特性、構造設計法 は米国で用いられているものであり、本研究で得られた知見が直接 日本の耐震設計に生かせるものではないと認識している。しかし、 蓄積されつつある地震動データ、載荷実験データ、解析プログラム やコンピューターの著しい発達を背景に、建物使用者の構造性能へ の多種多様の要求に応えるべく、確率論的アプローチを用いた性能 評価型の耐震設計は日本に限らず世界各国で今後ますます盛んにな ると想定されるが、筆者らは日本建築学会の本論文においてその評 価過程を具体的に展開、提示できたことに、我が国の構造設計の発 展に対して多少でも重要な貢献をできたのではないかと考えている。

\section{参考文献}

1) 秋山宏：構造物の耐震極限設計第 2 版、東京出版会、 1987 .

2) 和田 章、岩田 衛、清水 敬三、安部 重孝、河合 廣樹: 建築 物の損傷制御設計、丸善、1998。

3) 田川 浩之: Towards an Understanding of Seismic Performance of 3D Structures - Stability \& Reliability. Ph.D. Thesis; University of Washington, Seattle, USA. 2005.

4) 和田 章: 勒性確保は損傷覚悟、銅構造制振技術の現状と設計 指針への期待、2006 年度日本建築学会大会(関東)、構造部門(䤡 構造)、パネルディスカッション資料、2006.9.

5) FEMA: Connection Performance State of Art Report, FEMA-355D, Washington D.C. 2000.

6) Roeder, C. W. Redundancy and Ductility in Steel Moment Frames. UCB/EERC-97/05, 1997.
7）長谷川 隆、高橋 賢司、関 光雄、長尾 直治、向井 裕貴、福田 浩司: 日米の鉄骨造建物の耐震性能比較、日本建築学会大会学 術講演梗概集、C-1、構造 III、1998.

8) 六郷 美佳、長尾 直治：日米の鋼構造ラーメン骨組の耐震性状 に関する比較研究、日本建築学会大会学術講演梗概集、C-1、 構造 III、 2005.

9) Comell, C. A, Jalayer, F, Hamburger, R, and Foutch, D. Probabilistic Basis for 2000 SAC Federal Emergency Management Agency Steel Moment Frame Guidelines. Journal of Structural Engineering (ASCE); Vol. 128(4): 2002.

10) Cornell, A. and Krawinkler, H.: A Framework for Performance based Seismic Design, Proceedings of the 2001 Structures Congress and Exposition, Washington, D.C., 2001.

11) Kircher, C..: Earthquake Loss Estimation Methods for Welded Steel Monet-Frame Buildings, Earthquake Spectra, Vol. 19(2), 2003.

12) Pagni, C. and Lowes, L.: Fragility Functions for Older Reinforced Concrete Beam-Column Joints, Earthquake Spectra, Vol. 22(1), 2006.

13) Medina, R. and Krawinkler, H.: Seismic Demands for Nondeteriorating Frame Structures and their Dependency on Ground Motions, PEER Report No. 2003/15, 2003.

14) Cornell A.: Calculating Building Seismic Performance Reliability: A Basis for Multi-level Design Norms, Proceedings of $11^{\text {th }}$ World Conference on Earthquake Engineering, Acapulco, Mexico, 1996.

15) Federal Emergency Management Agency: Interim Guidelines: Evaluation, Repair, Modification and Design of Welded Steel Moment Frame Structures, FEMA-367, SAC-95-02, 1995.

16) Somerville, $P$. et al. Development of Ground Motion Time Histories for Phase 2 of the FEMA/SAC Steel Project, 1997; Rep. No. SAC/BD97/04, SAC Joint Venture, Sacramento, CA.

17) ICBO, International Conference of Building Officials. 1997 Uniform Building Code, Whittier, CA. 1997

18) MacRae, G. A. and Tagawa, H. Seismic Behavior of 3D Steel Moment Frame with Biaxial Columns. Journal of Structural Engineering (ASCE) 2001; Vol. 127(5): 490-497.

19) Powell G.H. and Campbell S.: DRAIN-3DX Base Program Description and User Guide - Version 1.10, UBC/SEMM-94/07, UC, Berkeley, Report No. UBC/SEMM-94/07,08, 1994.

20) Chopra, A.: Dynamics of Structures - Theory and Application to Earthquake Engineering, Prentice Hall, $2^{\text {nd }}$ Edition, 2001.

21) Vamvatsikos, D. and Cornell, C.: Incremental Dynamic Analysis. Earthquake Engineering and Structural Dynamics, Vol. 31(3), 2002.

22) FEMA: Recommended Seismic Design Criteria for New Steel Moment-Frame Buildings, FEMA-350, Washington D.C. 2000.

23) Nowak, A. and Collins, K. Reliability of Structures; McGraw-Hill: New York, 2000.

\section{謝辞}

本論文を執筆するに当たり、ワシントン大学教授のチャールズ ロ ーダー先生、東京工業大学助教授の山田哲先生、また本論文の查読 者から貴重なご意見を頂きました。ここに、感謝の意を表します。 